\title{
Трилобиты, биостратиграфия и геохимия куонамской свиты среднего кембрия (северо-восток Сибирской платформы, р. Кюленке
}

Коровников И. В., Парфенова Т. М.

\begin{abstract}
Аннотация
Изучена среднекембрийская часть разреза куонамской свиты на реке Кюленке (Сибирская платформа). Проведено биостратиграфическое расчленение разреза по трилобитам. В разрезе выявлены интервалы, соответствующие региональным зонам амгинского яруса среднего кембрия. Выявлено шесть уровней, к которым приурочены массовые скопления остатков фауны. Два уровня расположены в пределах зоны Ovatoryctocara; третий уровень располагается в пограничном интервале зон Ovatoryctocara и Kounamkites; четвертый - около кровли зоны Triplagnostus gibbus; пятый и шестой - в пределах зоны Tomagnostus fissus - Paradoxides sacheri.
\end{abstract}

Исследованы состав пород и битумоидов органического вещества (OB) пород. Рассмотрены особенности геохимии минеральных компонентов пород (железо, сера, CO2), насыщенных углеводородов битумоидов, изотопов некарбонатного углерода ОВ пород. Установлено, что седиментация ОВ происходила в условиях нормальной аэрации вод морского бассейна, без сероводородного заражения придонных вод. Интенсивность химических и биохимических трансформаций минеральных и органических компонентов в диагенезе контролировалась содержанием органического углерода, сульфат-иона, активностью анаэробного сообщества прокариот, скоростью минерализации осадков.

Выявлены связи между содержанием органического углерода в потенциально нефтематеринских породах и содержанием оксида железа, серы общей, серы сульфидной и сульфатной, соотношениями насыщенных углеводородов. Предполагается, что чередование высокоуглеродистых черных сланцев и углеродистых пород связано с изменением состава биологических сообществ микроорганизмов (источников углеводородов-биомаркеров) и интенсивности преобразования ОВ в диагенезе. Высказана гипотеза, что в диагенезе в неуплотненном морском осадке, обогащенном ОВ, при участии бактерий происходили сульфатредукция и деалкилирование высокомолекулярных стероидов. Интенсивность их зависела от массы исходного ОВ, количества сульфат-иона и, как следствие, pH и Eh среды.

Сибирская платформа, средний кембрий, куонамская свита, трилобиты, биостратиграфия, нефтематеринские породы, углерод, битумоид, углеводороды-биомаркеры, седиментация, диагенез.

Siberian platform, Middle Cambrian, Kuonamka Formation, trilobites, biostratigraphy, source rocks, carbon, butumen, biomarkers hydrocarbons, sedimentation, diagenesis.

\section{Ключевые слова:}

Сибирская платформа, средний кембрий, куонамская свита, трилобиты, биостратиграфия, нефтематеринские породы, углерод, битумоид 


\title{
ТРИЛОБИТЫ, БИОСТРАТИГРАФИЯ И ГЕОХИМИЯ \\ КУОНАМСКОЙ СВИТЫ СРЕДНЕГО КЕМБРИЯ (СЕВЕРО-ВОСТОК СИБИРСКОЙ ПЛАТФОРМЫ, Р. КЮЛЕНКЕ)
}

\author{
И. В. Коровников ${ }^{1,2}$, Т. М. Парфенова ${ }^{1,2}$
}

${ }^{1}$ Институт нефтегазовой геологии и геофизики им. А.А. Трофимука СО РАН, 630090, Новосибирск, просп. Коптюга, 3, Россия;

${ }^{2}$ Новосибирский государственный университет, 630090, Новосибирск, ул. Пирогова,1;

\section{E-mail: Korovnikoviv@ipgg.sbras.ru ; ParfenovaTM@ipgg.sbras.ru}

\section{Аннотация}

Изучена среднекембрийская часть разреза куонамской свиты на реке Кюленке (Сибирская платформа). Проведено биостратиграфическое расчленение разреза по трилобитам. В разрезе выявлены интервалы, соответствующие региональным зонам амгинского яруса среднего кембрия. Выявлено шесть уровней, к которым приурочены массовые скопления остатков фауны. Два уровня расположены в пределах зоны Ovatoryctocara; третий уровень располагается в пограничном интервале зон Ovatoryctocara и Kounamkites; четвертый - около кровли зоны Triplagnostus gibbus; пятый и шестой - в пределах зоны Tomagnostus fissus - Paradoxides sacheri.

Исследованы состав пород и битумоидов органического вещества (OB) пород. Рассмотрены особенности геохимии минеральных компонентов пород (железо, сера, $\mathrm{CO}_{2}$ ), насыщенных углеводородов битумоидов, изотопов некарбонатного углерода ОВ пород. Установлено, что седиментация ОВ происходила в условиях нормальной аэрации вод морского бассейна, без сероводородного заражения придонных вод. Интенсивность химических и биохимических трансформаций минеральных и органических компонентов в диагенезе контролировалась содержанием органического углерода, сульфат-иона, активностью анаэробного сообщества прокариот, скоростью минерализации осадков.

Выявлены связи между содержанием органического углерода в потенциально нефтематеринских породах и содержанием оксида железа, серы общей, серы сульфидной и сульфатной, соотношениями насыщенных углеводородов. Предполагается, что чередование высокоуглеродистых черных сланцев и углеродистых пород связано с изменением состава биологических сообществ микроорганизмов (источников 
углеводородов-биомаркеров) и интенсивности преобразования ОВ в диагенезе. Высказана гипотеза, что в диагенезе в неуплотненном морском осадке, обогащенном ОВ, при участии бактерий происходили сульфатредукция и деалкилирование высокомолекулярных стероидов. Интенсивность их зависела от массы исходного ОВ, количества сульфат-иона и, как следствие, pH и Eh среды.

Сибирская платформа, средний кембрий, куонамская свита, трилобиты, биостратиграфия, нефтематеринские породы, углерод, битумоид, углеводородыбиомаркеры, седиментация, диагенез.

Siberian platform, Middle Cambrian, Kuonamka Formation, trilobites, biostratigraphy, source rocks, carbon, butumen, biomarkers hydrocarbons, sedimentation, diagenesis.

\section{ВВЕДЕНИЕ}

Куонамская свита, охарактеризованная породами с повышенным содержанием органического вещества (OB), имеет широкое распространение на территории восточной части Сибирской платформы [Савицкий и др., 1972; Бахтуров и др., 1988; Старосельцев, Шишкин, 2014 и др.]. Стратиграфический интервал свиты распространяется от низов ботомского яруса нижнего кембрия до верхов амгинского яруса среднего кембрия. Они содержат огромное количество разнообразных остатков кембрийской биоты (трилобиты, брахиоподы, мелкораковинная фауна и др.) и являются уникальным объектом как для палеонтологических исследований, так и для изучения геохимии органического и минерального вещества.

На обширной территории восточной части Сибирской платформы имеется большое количество разрезов куонамской свиты, которые выходят на дневную поверхность в береговых обнажениях рек, а также вскрыты скважинами. Однако, детальное изучение трилобитов и биостратиграфического расчленения куонамской свиты было проведено только в нескольких разрезах. Так, были изучены разрезы на реках Некекит и Бороулах [Савицкий и др., 1972], на реке Молодо [Шабанов и др., 2008; Коровников, Шабанов, 2008], на реке Оленек в среднем течении [Коровников, Шабанов, 2016].

Для того чтобы дополнить знания и информацию о биостратиграфии кембрийских черносланцевых отложений на северо-востоке Сибирской платформы авторами был изучен разрез куонамской свиты, расположенный в среднем течении реки Кюленке (левый приток р. Лены). Ранее описание этого разреза было представлено в монографии [Бахтуров и др., 1988]. Биостратиграфическое расчленение разреза и изучение остатков ископаемой фауны в этой работе не приводились. Было лишь указано, что в нижней части 
разреза куонамской свиты встречаются массовые представители родов Bergeroniellus Lermontova, 1940 и Delgadella Walcott, 1912 в верхней - редкие находки трилобитов семейства Oryctocephalidae.

Первые сведения о геохимии ОВ потенциально нефтематеринских пород и битумов куонамской свиты из разреза на реке Кюленке обсуждались в публикациях [Бахтуров и др., 1988; Каширцев, 2003; Парфенова и др., 2011; 2014]. По пиролитическим и биомаркерным параметрам выполнена оценка катагенеза ОВ. Сделан вывод, что ОВ пород куонамской свиты соответствует ОВ стадии мезокатагенеза, породы из обнажений на территории Мунского свода погружались в главную зону нефтеобразования и генерировали нефти. Актуальными остаются вопросы, связанные с исследованием накопления и преобразования углеродистых осадков на Сибирской платформе [Старосельцев, Шишкин, 2014; Parfenova, 2017, 2018]. Выявленные закономерности распределения ОВ, индивидуальных УВ, неорганического материала в породах, могут служить основой для реконструкции палеогеографии куонамской свиты, оценки ресурсов и качества горючих сланцев, распространенных в отложениях нижнего и среднего кембрия, прогноза состава нефтей на Сибирской платформе. Для этого необходимо дополнительное изучение геохимии минеральных и органических компонентов пород из разрезов кембрия, в том числе и из разреза на р. Кюленке. Поэтому настоящая работа, кроме детального биостратиграфического расчленения куонамской свиты, была направлена на поиск факторов, контролирующих сохранность следов палеонтологических и химических остатков биоты в породах, условий формирования обогащенных ОВ осадков. Авторами ставилась задача проанализировать геохимические особенности пород и ОВ в обогащенных и обедненных остатками ископаемой фауны интервалах разреза на реке Кюленке, которые соответствуют установленным биостратиграфическим подразделениям по трилобитам.

\section{МАТЕРИАЛЫ И МЕТОДЫ}

В ходе экспедиционных работ летом 2005 года было изучено два береговых обнажения (K-1, K-2) на реке Кюленке (рис. 1, 2), в которых представлена верхняя часть куонамской свиты (25 м). Ранее в этом разрезе было выделено семь пачек [Бахтуров и др., 1988, с.15-18], которые имеют суммарную мощность около 33 метров. В изученной нами части разреза отсутствуют две нижние пачки суммарной мощностью примерно 6,5 м. Изученный разрез включает в основном среднекембрийскую часть куонамской свиты. При изучении разреза проводилось послойное описание разреза, послойный сбор остатков трилобитов, дальнейшая механическая препарировка найденных остатков. При 
определении возраста применялся метод биостратиграфического анализа находок трилобитов.

Для установления особенностей условий осадконакопления и для поиска факторов, контролирующих сохранность следов палеонтологических и химических остатков биоты в породах, обогащенных ОВ, проводились геохимические исследования. Для этих исследований отобранные образцы породы дробили до 0,25 мм. Обрабатывали 10 \% соляной кислотой для получения нерастворимого остатка (НО). На экспресс-анализаторе АН-7529 методом сожжения в кислороде проб НО определяли содержание органического углерода $\left(\mathrm{C}_{\text {орг }}\right)$ в породах (19 образцов). Общее содержание железа, серы $\left(\mathrm{S}_{\text {общ}}\right)$, форм серы (сера сульфидная ( $\left.\mathrm{S}_{\text {сульфид }}\right)$, сера сульфатная $\left(\mathrm{S}_{\text {сульфат }}\right)$ ), вклад $\mathrm{CO}_{2}$ анализировали химическим методом (19 образцов). Битумоид экстрагировали из 50 граммовых навесок дробленых пород (15 образов) хлороформом при комнатной температуре с применением центрифуги. После очистки экстракта ртутью от элементарной серы петролейным эфиром из битумоида выделяли асфальтены. Далее мальтены делили на фракции насыщенных углеводородов (УВ), ароматических соединений и смол (15 образцов). Алканы метанонафтеновой фракции (15 образцов) анализировали на хроматографе «5890 series II Gas Chromatograph» с использованием капиллярной колонки с фазой HP-5 при начальной температуре $40{ }^{\circ} \mathrm{C}$ и конечной $-290{ }^{\circ} \mathrm{C}$. Насыщенные полициклические УВ изучали на хромато-масс-спектрометрической системе Agilent 5973N (газовый хроматограф 6890 с высокоэффективным масс-селективным детектором и компьютерной системой регистрации) при температуре $100-320{ }^{\circ} \mathrm{C}$. Хроматограф снабжен кварцевой капиллярной колонкой длиной 30 м, диаметром 0.25 мм с импрегнированной фазой HP-5MS. Скорость потока газа-носителя гелия 1 мл/мин. Идентификация соединений осуществлялась по времени удерживания и путем сравнения спектров индивидуальных молекул, сканированных образцов, со спектрами электронной библиотеки, а также опубликованными данными. Измерения изотопного состава углерода бескарбонатного вещества 10 проб НО выполняли на масс-спектрометре МИ 1201В относительным методом, который заключается в попеременном измерении ионных токов двух масс 44, 45 образца и стандарта, представляющих собой газ $\left(\mathrm{CO}_{2}\right)$.

Высокие значения битумоидного коэффициента и индекса продуктивности по пиролизу, а также наличие молекулярных признаков бактериального окисления насыщенных УВ позволили кроме макроскопических (K-1-7a, K-1-7с, рис. 2) диагностировать рассеянные битумопроявления (K-1-5, K-1-7b, K-1-8, K-2-6a) в породах куонамской свиты [Парфенова и др., 2011, 2014]. Эти образцы помечены звездочкой (рис. 2). Геохимия их УВ в статье не обсуждается. 


\section{РЕЗУЛЬТАТЫ И ИХ ОБСУЖДЕНИЕ}

Разрез куонамской свиты. Куонамская свита согласно залегает на еркекетской свите (глинистые известняки). Сложена черными битуминозными известняками, сланцами и кремнистыми породами. Согласно перекрывается оленекской свитой (глинисные, зеленовато-серые известняки). Нижние около 8 м куонамской свиты не были изучены. По опубликованным данным [Бахтуров и др., 1988] нижняя часть свиты (2,45 м) представлена в основном черными битуминозными аргиллитами. В основании прослой рыхлой, глинистой породы зеленовато-желтого цвета, содержащий обломки черных биодетритовых известняков (0,15-0,2 м). В средней части прослой темно-серых известняков, образующих линзовидные тела. Примерно в 1 м от подошвы встречены трилобиты родов Bergeroniellus Lermontova, 1940 и Delgadella Walcott, 1912 [Бахтуров и др., 1988]. Выше залегают ритмично переслаивающиеся черные битуминозные породы: кремни тонко- и среднеплитчатые, часто известковые, аргиллиты (4 м). Встречаются линзовидные тела черных мелкокристалических известняков, которые облекаются аргиллитами и кремнями. В 2,1 м от основания этого интервала встречаются остатки трилобитов Lermontovia Suvorova, 1956 и Neopagetina Pokrovskaya, 1960 [Бахтуров и др., 1988].

Вышележащая часть разреза была изучена авторами в ходе полевых работ. Выделено несколько пачек.

Пачка 1. Представляет собой чередование черных кремнистых известняков, силицитов и черных сланцев. Преобладают известняки. Мощность пропластков известняков 8-10 см, мощность пропластков сланцев 2-3 см. На нескольких уровнях встречены маломощные прослои (5 см) рыхлого песчанистого известняка. В 4 м от основания пачки - прослой менее кремнистого известняка. В 3 м от подошвы встречены спикулы губок. В 6,3 м от подошвы пачки - трилобиты Oryctocephalops frischenfeldi Lermontova, 1940 (рис. 2, K-2-18,7; табл.1, фиг. 1-3). В 8 м от подошвы - трилобиты Perononsis sp., Pagetides spinosus Lazarenko, 1959 (рис. 2, К-2-17; табл.1, фиг 4, 5), многочисленные остатки брахиопод семейства Acrotretidae. Видимая мощность пачки $8,7 \mathrm{M}$

Пачка 2. Чередование тонких прослоев черных кремнистых известняков (мощность пропластков 3-5 см), силицитов и черных аргиллитов (мощность пропластков 3-4 см). Около кровли встречены трилобиты (рис. 2, K-2-15,5) Peronopsis integra (Beyrich, 1845) (табл. 1, фиг. 14), Pagetia ferox Lermontova, 1940 (табл. 1, фиг. 7), Oryctocephalus reticulatus (Lermontova, 1940) (табл.1, фиг. 8), Kounamkites virgatus N.Tchernysheva, 1956 
(табл.1, фиг. 6), неопределимые трилобиты семейства Anomocaridae, также встречены многочисленные остатки брахиопод семейства Acrotretidae. Мощность пачки 1,5 м.

Пачка 3. Чередование прослоев черных кремнистых известняков, силицитов и черных аргиллитов аналогичное пачки 2, но мощность прослоев известняков больше (1015 см), мощность прослоев аргиллитов (0,5-1 см). В подошве пачки (рис. 2, K-2-15,3) встречены трилобиты Oryctocephalus reticulatus (Lermontova, 1940) (табл. 1, фиг. 10), Kounamkites virgatus N.Tchernysheva, 1956, Pagetia ferox Lermontova, 1940 (табл. 1, фиг. 9), Peronopsis integra (Beyrich, 1845) (табл. 1, фиг. 11. 13). Мощность пачки 1,8 м.

Пачка 4. Чередование прослоев черных кремнистых известняков, силицитов и тонких прослоев черных аргиллитов. Мощность - 3 м.

Пачка 5. Чередование тонких прослоев черных кремнистых известняков и прослоев черных аргиллитов. Преобладают аргиллиты. В 0,5 м от подошвы пачки наблюдается рыхлый глинистый прослой (5 cм) желтого цвета. В подошве встречены трилобиты Oryctocephalus reticulatus (Lermontova, 1940) (табл. 1, фиг. 12), Triplagnostus gibbus (Linnarsson, 1869), Peronopsis sp. (рис. 2, K-2-10,5) и акротретидные брахиоподы. Мощность - 2,5 м.

Пачка 6. Чередование прослоев черных кремнистых известняков и прослоев черных аргиллитов, аналогичное пачке 5, но мощность прослоев меньше (5-8 см известняки; 3-4 см - аргиллиты). В разрезе 2 около кровли пачки найдены брахиоподы Eoobolus sp. и трилобиты Triplagnostus gibbus (Linnarsson, 1869) (рис. 2, K-1-5,3; табл. 1, фиг. 15, 16, табл. 2 фиг. 1), в 1,8 м от кровли - спикулы губок. Мощность - 3,0 м.

Пачка 7. (Малокуонамский маркирующий горизонт) Известняки серые, темносерые, комковатые, волнистослоистые. В обнажении К-2 в подошве пачки брахиоподы. В обнажении К-1 в кровле пачки встречены неопределимые обломки раковин брахиопод.

Мощность - 1,4 м в разрезе 1 и 1,6 м в разрезе 2.

Пачка 8. (Маспакыйский маркирующий горизонт). Чередование черных, битуминозных известняков, окремненных и черных сланцев. Во всей пачке встречаются агностидные трилобиты: Triplagnostus gibbus (Linnarsson, 1869) найдены в 3,5 и 3,4 м от кровли (рис. 2, K-1-3,5; K-1-3,4; табл. 2, фиг. 2-5), Tomagnostus fissus (Lungren, 1879) (рис. 2, K-1-3,2; табл. 2, фиг. 6, 7), Triplagnostus gibbus (Linnarsson, 1869) (табл. 2, фиг. 9) встречены в 3,2 м от кровли (рис. 2, K-1-3,2), в 2 м от кровли встречены неопределимые обломки агностидных трилобитов, в 1 м от кровли и в самой кровле найдены Triplagnostus gibbus (Linnarsson, 1869) (табл. 1, фиг. 8), Aotagnostus (Myrmecomimus) arctus (Pokrovskaya et Egorova, 1976) (рис. 2, K-1-1,0 и К-1-0; табл. 2, фиг. 10-14). Мощность - 3,4 в разрезе 2 3,6 м в разрезе 1 . 
Видимая мощность куонамской свиты - 25,3-25,7 м.

Свита согласно перекрывается оленекской свитой, которая представлена зеленовато-серыми, желтоватыми волнистослоистыми глинистыми известняками.

\section{Биостратиграфия среднекембрийской части куонамской свиты.}

Как показано выше, изученная верхняя часть куонамской свиты составила 25,3-25,7 м. По данным С.Ф. Бахтурова и др. [Бахтуров и др., 1988] полная мощность свиты в этом разрезе составляет 31,6 - 33,2 м. Таким образом нами осталась не изучена нижняя часть свиты мощностью около 8 м. Первые трилобиты, характерные для низов среднего кембрия в разрезе встречены в 6,3 от начала видимой части куонамской свиты в разрезе 2 (рис. 2). Таким образом, получается, что первые находки среднекембрийских трилобитов появляются на уровне около 14 м от подошвы свиты. В детально изученном разрезе куонамской свиты на реке Молодо [Коровников, Шабанов, 2008], нижняя граница среднего кембрия устанавливается в 13,4 м от подошвы свиты. В разрезе на реке Некекит первые среднекембрийские трилобиты появляются в разрезе на уровне 15,15 м от подошвы свиты [Савицкий и др., 1972]. Однако стоит отметить, эти разрезы имеют большую мощность (более 50 м). Сопоставимую мощность куонамской свиты с изучаемым разрезом имеет разрез на реке Оленек в среднем течении [Коровников, Шабанов, 2016]. Там мощность куонамской свиты 27 м, а нижняя граница устанавливается в 11,05 м от ее подошвы. Таким образом, учитывая эти данные, с большой долей уверенности по первым находкам трилобитов Oryctocephalops frischenfeldi Lermontova, 1940 в 6,3 м от подошвы пачки 1 можно установить нижнюю границу среднего кембрия в изучаемом разрезе. Встреченные несколько выше (в 8 м от подошвы) трилобиты Perononsis sp., Pagetides spinosus Lazarenko, 1959 (K-2-17) также характерны для низов среднего кембрия. Эти виды в других разрезах куонамской свиты встречаются в пределах первых двух региональных зон амгинского яруса Ovatoryctocara и Kounamkites.

В самых верхах пачки 2 (рис. 2) найдены трилобиты Peronopsis sp., Pagetia ferox Lermontova, 1940, Oryctocephalus reticulatus (Lermontova, 1940), Kounamkites virgatus N.Tchernysheva, 1956 (K-2-15,5). Два последних вида указывают на принадлежность этого уровня к региональной зоне Kounamkites (вторая зона амгинского яруса). Трилобиты этой же зоны встречены и в подошве пачки 3; Oryctocephalus reticulatus (Lermontova, 1940), Kounamkites virgatus N.Tchernysheva, 1956, Pagetia sp., Peronopsis integra (Beyrich, 1845) (K-2-15,3).

Выше по разрезу, около подошвы пачки 5 встречены трилобиты Oryctocephalus reticulatus (Lermontova, 1940), Triplagnostus gibbus (Linnarsson, 1869), Peronopsis sp. и 
акротретидные брахиоподы (K-2-10,5). Присутствие в комплексе трилобитов Triplagnostus gibbus (Linnarsson, 1869) сопоставить этот уровень с региональной зоной Triplagnostus gibbus. Таким образом, интервал разреза куонамской свиты от 6,3 м от начала разреза (пачка 1) до подошвы пачки 5 мощностью 8,7 м можно сопоставить с интервалом двух первых региональных зон Ovatoryctocara и Kounamkites амгинского яруса. Условно границу между этими зонами можно провести по появлению в разрезе трилобитов Kounamkites virgatus N.Tchernysheva, 1956 в верхах пачки 2. Но следует заметить, что трилобиты Oryctocephalops frischenfeldi Lermontova, 1940, Pagetides spinosus Lazarenko, 1959, встреченные ниже, могут присутствовать в пределах двух первых зон амгинского яруса.

Как уже упоминалось выше, первые трилобиты Triplagnostus gibbus (Linnarsson, 1869) найдены около подошвы пачки 5 (рис. 2). Они же встречаются выше по разрезу в кровле шестой пачки (K-1-5,3) и в низах пачки 8 (K-1-3,5).

Седьмая пачка - это малокуонамской маркирующий горизонт, в котором в других разрезах куонамской свиты, начиная с его подошвы встречаются трилобиты, характеризующие зону Tomagnostus fissus - Paradoxides sacheri амгинского яруса. В разрезе на реке Кюленке трилобиты этой зоны были встречены в только в пачке 8. Таким образом, вероятно, к региональной зоне Triplagnostus gibbus можно отнести интервал разреза мощностью 5,5 метра (пачки 5 и 6).

K вышележащей региональной зоне Tomagnostus fissus - Paradoxides sacheri, вероятно относится пачка 7 (малокуонамский маркирующий горизонт), по аналогии с другими разрезами, и пачка 8 (маспакыйский маркирующий горизонт), в которой практически с подошвы встречаются многочисленные трилобиты Triplagnostus gibbus (Linnarsson, 1869), Tomagnostus fissus (Lungren, 1879), Aotagnostus (Myrmecomimus) arctus (Pokrovskaya et Egorova, 1976) типичные для этой зоны. Таким образом, верхние 5,0 м куонамской свиты соответствуют низам региональной зоны Tomagnostus fissus Paradoxides sacheri. По данным из других разрезов, комплекс характерный для этой зоны продолжает встречаться в низах вышележащей оленекской свиты.

Таким образом, в изученной части куонамской свиты, основываясь на находках трилобитов, устанавливается та же последовательность комплексов трилобитов, что и в других более детально изученных разрезах, характерная для региональных зон амгинского яруса среднего кембрия.

Так, интервал разреза от 6,3 м до 15 м (мощностью 8,7 м) сопоставляется с региональными зонами Ovatoryctocara и Kounamkites. Условно границу между этими 
зонами можно установить на уровне 10,3 м от начала разреза 2 по появлению трилобитов Kounamkites virgatus N.Tchernysheva, 1956.

Интервал разреза 2 от 15,0 м до 20,5 м сопоставляется с региональной зоной Triplagnostus gibbus. Подошва устанавливается по появлению в разрезе вида-индекса Triplagnostus gibbus (Linnarsson, 1869), кровля по подошве пачки 7 (малокуонамский маркирующий горизонт), поскольку в других разрезах куонамской свиты именно там начинают встречать трилобиты типичные для следующей региональной зоны.

C низами региональной зоной Tomagnostus fissus - Paradoxides sacheri сопоставляется верхняя часть куонамской свиты в изученных разрезах (пачки 7 и 8, малокуонамский и маспакыйский маркирующие горизонты) поскольку в пределах маспакыйского горизонта (пачка 8) встречены типичные представители этой зоны.

Особенности комплексов трилобитов. Комплексы трилобитов в изученном разрезе являются типичными для среднекембрийской части куонамской свиты. В других разрезах они присутствуют в этой же части свиты [Савицкий и др, 1972; Шабанов и др., 2008, Коровников, Шабанов, 2016 и др.]. Однако комплексы трилобитов имеют некоторые особенности. Так, наблюдается существенное уменьшение как численности, так и таксономического разнообразия комплексов трилобитов по сравнению с разрезами, расположенными в северо-восточной части Сибирской платформы (реки Молодо, Некекит, Бороулах и др.). В разрезе на реке Кюленке обнаружено 9 видов трилобитов. В аналогичном среднекембрийском интервале разреза куонамской свиты на реке Молодо встречено более 40 видов трилобитов [Шабанов и др., 2008].

Кроме этого обращает на себя внимание тот факт, что находки трилобитов приурочены к нескольким уровням, на которых остатки трилобитов встречаются в изобилии. Между этими уровнями встречаются редкие неопределимые обломки трилобитов.

Первый такой уровень отмечается в 6,3 м от подошвы пачки 1. Там в большом количестве встречены остатки Oryctocephalops frischenfeldi Lermontova, 1940. Следующий уровень с массовыми остатками трилобитов Perononsis sp., Pagetides spinosus Lazarenko, 1959 отмечен в 8 м от подошвы пачки 1. Здесь же встречаются многочисленные остатки брахиопод семейства Acrotretidae. Третий уровень массовых находок трилобитов в разрезе приходится на пограничный интервал между второй и третьей пачками. В кровле второй пачки и в подошве третьей пачки встречены многочисленные остатки трилобитов Peronopsis sp., Pagetia ferox Lermontova, 1940, Oryctocephalus reticulatus (Lermontova, 1940), Kounamkites virgatus N.Tchernysheva, 1956, многочисленные остатки брахиопод 
семейства Acrotretidae и трилобиты Oryctocephalus reticulatus (Lermontova, 1940), Kounamkites virgatus N.Tchernysheva, 1956, Pagetia sp., Peronopsis integra (Beyrich, 1845).

Следующий уровень массовых находок трилобитов приурочен к верхам пачки 6. Здесь встречены многочисленные остатки трилобитов Triplagnostus gibbus (Linnarsson, 1869) и брахиоподы Eoobolus sp. Выше по разрезу в низах пачки 8 в разрезе наблюдается интервал разреза мощностью 0,5 м, в пределах которого остатки трилобитов Triplagnostus gibbus (Linnarsson, 1869) встречаются в большом количестве. Здесь же в несколько меньшем количестве найдены трилобиты Tomagnostus fissus (Lungren, 1879).

В самой кровле куонамской свиты встречены многочисленные остатки трилобитов Triplagnostus gibbus (Linnarsson, 1869), Aotagnostus (Myrmecomimus) arctus (Pokrovskaya et Egorova, 1976).

Таким образом, в среднекембрийской части разреза куонамской свиты наблюдаются шесть уровней с массовыми остатками трилобитов и брахиопод. Два уровня расположены в пределах зоны Ovatoryctocara; третий уровень располагается в пограничном интервале зон Ovatoryctocara и Kounamkites; четвертый - около кровли зоны Triplagnostus gibbus; пятый и шестой - в пределах зоны Tomagnostus fissus - Paradoxides sacheri.

Геохимия пород и углеводородов. Состав пород куонамской свиты обнажения р. Кюленке представлен в таблице 3. Выделена группа высокоуглеродистых черных сланцев глинисто-кремнистого состава с содержанием $\mathrm{C}_{\text {орг }}$ на уровне 10 \% и больше. Содержание $\mathrm{HO}$ и $\mathrm{CO}_{2}$ в породах указывают, что они редко обогащены карбонатным материалом. Черные сланцы, как правило, имеют повышенные значения общего содержания $\mathrm{Fe}_{2} \mathrm{O}_{3}$ и $\mathrm{S}$.

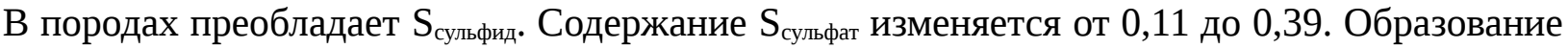
сульфатов связано с окислением сульфидов минеральных и органических компонентов пород куонамской свиты в зоне гипергенеза. Установлено, что отношение пиритного железа к $\mathrm{C}_{\text {орг }}$ лежит в интервале 0,13-0,28 (табл. 3). Этот тип пород встречен в нижней и средней частях разреза.

В изученном материале также выявлены углеродистые породы с содержание $\mathrm{C}_{\text {орг }}$ меньше 10\%. Среди них в основном присутствуют породы смешанного состава (глинистокремнистые известняки, глинисто-карбонатно-кремневые породы), встречаются черные силициты (табл. 3). Содержание $\mathrm{Fe}_{2} \mathrm{O}_{\text {зобщ, }} \mathrm{S}_{\text {общ, }} \mathrm{S}_{\text {сульфид }}$ и $\mathrm{S}_{\text {сульфат }}$ понижено. Отношение $\mathrm{Fe}_{\text {пирит }} / \mathrm{C}_{\text {орг }}$ изменяется от 0,07 до 0,92, минимальные значения характеризуют силициты.

Установлены типичные для обогащенных ОВ пород прямые зависимости между

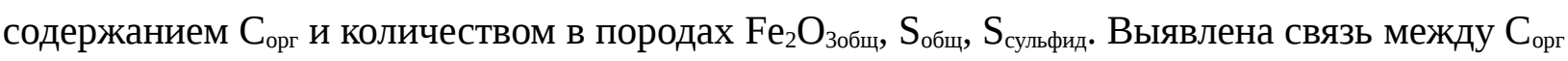

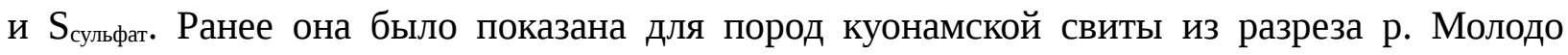
[Парфенова и др., 2010]. 
Выход битумоида в черных сланцах изменяется от 0,04 до 0,09 \%. В их составе содержание насыщенных УВ равно 7,6-16,1 \%, ароматических соединений - 34,8-55,5 \%, смол - 27,6-54,8 \%, асфальтеновых компонентов - 0,9-3,5 \%. В углеродистых породах смешанного состава и силицитах выход битумоида больше, он варьирует от 0,03 до 0,21\%. Битумоиды углеродистых пород содержат 9,8-21,4 \% насыщенных УВ, 20,7-39,9 \% ароматических соединений, 36,1-48,3 \% смол, 3,6-33,4 \% асфальтеновых компонентов. Аномально высокие концентрации асфальтенов (больше 15\%) установлены в силицитах.

Детально результаты изучения сингенетичных битумоидов рассеянного ОВ, битумов и их насыщенных УВ потенциально нефтематеринских пород из разрезов р. Кюленке представлены в публикациях [Парфенова и др., 2011; Каширцев, 2003]. В настоящей работе обратим внимание на соотношение некоторых индивидуальных УВ, состав стеранов и терпанов (табл. 4) для решение поставленных задач.

Отношения алканов в битумоидах пород имеют близкие значения (табл. 4). Соотношение пристана $(\mathrm{Pr})$ к фитану $(\mathrm{Ph})$ изменяется от 0,7 до 1,5 , отношение $\mathrm{Pr} / \mathrm{n}-\mathrm{C}_{17}-$ oт 0,3 до 0,8, Ph/n-C 18 - от 0,4 до 1,2 (табл. 4, рис. 3).

На масс-хроматограммах по m/z 217 идентифицированы стераны $\mathrm{C}_{27-30}$ и прегнаны

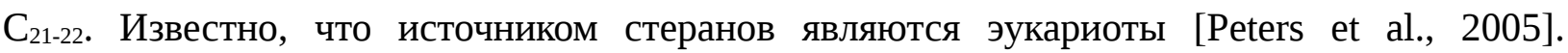
Распределение стеранов в высокоуглеродистых черных сланцах и углеродистых породах отличается. В последних обычно преобладают этилхолестаны. Их содержание достигает $53,5 \%$ на сумму гомологов. Отношение стеранов $\mathrm{C}_{29} / \mathrm{C}_{27}$, как правило, больше 2 (табл. 4). Среди насыщенных УВ битумоидов высокоуглеродистых черных сланцев содержание холестанов $\left(\mathrm{C}_{27}\right)$ изменяется от 36 до 44 \%, метилхолестанов $\left(\mathrm{C}_{28}\right)$ - от 13 до 21 \%, этилхолестанов $\left(\mathrm{C}_{29}\right)$ - от 36 до 48 \%. Концентрации пропилхолестанов $\left(\mathrm{C}_{30}\right)$ сохраняются на уровне 2 \%. Как в битумоидах куонамской и иниканской свит из разрезов, изученных ранее, относительное содержание прегнанов возрастает с увеличением содержания в

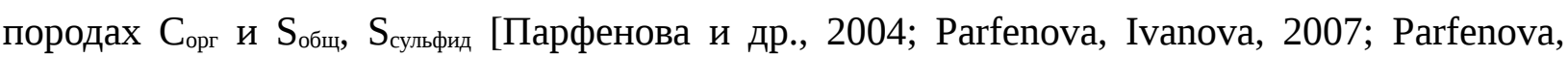
2017]. В высокоуглеродистых сланцах отношение стераны/прегнаны изменяется от 1,1 до 1,8, в углеродистых породах - от 2,6 до 4,1 (табл. 4).

Терпаны насыщенных фракций идентифицированы на хроматограммах по m/z 191. Установлено, что в составе терпанов преобладают трицикланы (табл. 4). Происхождение этих УВ связывают с развитием в биологическом сообществе Tasmanites (празинофиты) и Leiosphaeridia (вымершие водоросли или акритархи) [Dutta et al., 2006; Greenwood et al., 2000]. В насыщенных УВ битумоидов высокоуглеродистых черных сланцев трицикланов больше, чем в породах смешанного состава и силицитах. Гопанов, источником которых признаны бактерии [Peters et al., 2005], больше в УВ углеродистых пород. Соответственно, 
для черных сланцев наблюдаются повышенные значения отношения трицикланы $/ \Sigma$ (гопаны+гомогопаны) до 2,7 (табл. 4). Среди гомогопанов с ростом молекулярной массы содержание гомологов уменьшается. Отношение гомогопанов $\mathrm{C}_{35} \mathrm{~K}$ $\mathrm{C}_{34}$ изменяется от 0,5 до 0,7. Тетрацикланы и моретаны имеют минимальные содержания среди терпанов. Следует обратить внимание на изменение соотношения суммы стеранов и прегнанов к сумме терпанов. Минимальные значения на уровне 0,3 характеризуют УВ черных силицитов. Зависимость этого параметра от содержания $\mathrm{C}_{\text {орг }}$ в породах отсутствует. Обнаружено, что значения отношения (стераны+прегнаны)/терпаны увеличивается с ростом содержания $\mathrm{S}_{\text {общ }}$ и $\mathrm{S}_{\text {сульфид. }}$ На хроматограммах по m/z 191 во всех образцах идентифицирован гаммацеран. Его содержание на сумму терпанов изменяется, как правило, от 0,02 до 0,77, в одном образце достигает 1,61 \%. Впервые установлено, что с увеличением содержания гаммацерана растет значение отношения $\mathrm{Fe}_{\text {пирит }} / \mathrm{C}_{\text {орг }}$.

Для некарбонатного углерода пород значения $\delta^{13} \mathrm{C}$ близки. Они изменяются от $-32,6$ до -30,3 \%о и не зависят от состава пород и содержания в них $\mathrm{C}_{\text {орг. }}$

Условия формирования куонамских осадков. Распределение ОВ в разрезе, чередование высокоуглеродистых черных сланцев, углеродистых пород смешанного состава и силицитов, охарактеризованных разным соотношением стерановых и терпановых УВ, указывают, что в куонамском морском бассейне происходила смена микробиоценозов. В состав биологических сообществ, кроме макроформ, входили археи, водоросли и бактерии. Вероятно, периоды развития в бассейне водорослевого планктона приводили к накоплению аномального количества ОВ в осадке и формированию впоследствии высокоуглеродистых черных сланцев. На фоне затухания этого процесса возрастал вклад бактериальных организмов в ОВ, накапливались осадки, обогащенные ОВ в меньшей степени.

Выше было показано, что скопления остатков трилобитов приурочены к узким интервалам разреза. Поскольку в изученном разрезе придонная фауна, в том числе и трилобитовая, присутствует только в нескольких узких интервалах и представлена несколькими видами, адаптированными к существующим условиям, можно рассматривать следующие гипотезы. Во-первых, предположить, что осадконакопление проходило преимущественно в аноксических обстановках. Во-вторых, связать интервалы разреза, охарактеризованные находками трилобитов, с периодами кратковременного исчезновения аноксии в результате попадания в палеобассейн вод, обогащенных кислородом. Такая ситуация известна для палеобассейнов с аноксическими обстановками. При исследовании кембрийских пород, обогащенных органическим веществом (формация Alum Shale, 
Скандинавия), было установлено, что остатки фауны приурочены к прослоям пород, которые накапливались при кратковременном повышенном содержании кислорода [Dahl et al., 2019]. Однако, геохимическими исследованиями установлено, что седиментация ОВ происходила в условиях нормальной аэрации вод морского бассейна. Поэтому причины имеющегося распределения макробиоты в разрезе, вероятно, надо искать в другом.

Рассмотрим геохимические параметры, которые являются индикаторами условий накопления и преобразования минерального и органического вещества пород на этапах седиментации и диагенеза.

Распределение гомогопанов, гомогопановый индекс $\mathrm{C}_{35} / \mathrm{C}_{34}$ меньше 1 , содержание гаммацерана менее 1\% [Santos Neto et al., 1998, Каширцев, 2003; Peters et al., 2005] указывают, что во время седиментогенеза не было стратификации и аноксии придонных вод. Сильно восстановительные условия были ниже границы воды с осадком. Об этом свидетельствует положение образцов на диаграмме УВ (рис. 3) [Connan, Cassou, 1980]. Значения отношения $\mathrm{Fe}_{\text {пирит }} / \mathrm{C}_{\text {орг }}$ [Страхов, Залманзон, 1955] подтверждают это. Известно, что в пресноводных субокислительных обстановках соотношение пиритного железа к органическому углероду меньше 0,03-0,06, в морских восстановительных больше 0,1-0,2 [Страхов, Залманзон, 1955]. Вариации отношения $\mathrm{Fe}_{\text {пирит }} / \mathrm{C}_{\text {орг }}$ свидетельствуют, что преобразование высокоуглеродистых черносланцевых осадков шло в более восстановительных условиях, чем углеродистых карбонатных и кремневых илов. Это отразилось на содержании в УВ осадков гаммацерана, который является индикатором аноксии и солености [Peters et al., 2005]. Серия представленных выше связей показывает, что интенсивность сульфатредукции контролировалась количеством ОВ и содержанием сульфатов. Она была выше при формировании высокоуглеродистых осадков, по сравнению с обедненными ОВ илами. Закономерное повышение содержания низкомолекулярных стеранов (прегнанов) в породах указывает на рост активности алкилотрофных анаэробных бактерий с увеличением содержания ОВ, поступающего в осадок. Биодеградация (деалкилирование) высокомолекулярных стерановых УВ черносланцевых осадков была выше, чем углеродистых илов. Вероятно, скорость минерализации преимущественно карбонатных и кремневых осадков была больше, что дополнительно приводило к обеднению известняков и силицитов органическим веществом, по сравнению с высокоуглеродистыми сланцами. Повышенная скорость минерализации карбонатных и кремневых илов подавляла деятельность анаэробных прокариот, прекращались сульфатредукция и деалкилирование стеранов. 


\section{ЗАКЛЮЧЕНИЕ}

В изученной части куонамской свиты, основываясь на находках трилобитов, устанавливается та же последовательность комплексов трилобитов, что и в других более детально изученных разрезах, характерная для региональных зон амгинского яруса среднего кембрия. Установлены интервалы разреза, соответствующие региональным зонам Ovatoryctocara и Kounamkites, зоне Triplagnostus gibbus и нижней части зоны Tomagnostus fissus - Paradoxides sacheri амгинского яруса среднего кембрия.

Комплексы трилобитов в изученном разрезе являются типичными для среднекембрийской части куонамской свиты. Однако, комплексы имеют некоторые особенности, которые выражены в существенном уменьшение численности и таксономического разнообразия по сравнению с другими разрезами (разрезы на реках Молодо, Некекит, Бороулах и др.).

В изученном разрезе в среднекембрийской части куонамской свиты наблюдаются шесть уровней с массовыми остатками трилобитов и брахиопод. Три уровня приурочены к низам среднего кембрия и приурочен первой зоне амгинского яруса среднего кембрия Ovatoryctocara. Три других уровня наблюдаются в верхах куонамской свиты, в верхних 5 метрах.

Анализ распространения фаунистических остатков в разрезе показал, что массовые скопления остатков трилобитов приурочены к породам смешанного состава. В черных силицитах и известняках трилобиты встречены не были. Сохранность насыщенных УВ биомаркеров и изотопов некарбонатного углерода, характеризующих рассеянное зрелое OB, не зависит от литологии пород.

Сравнительный анализ содержания минеральных компонентов и углеводородов битумоидов пород интервалов разреза вблизи находок трилобитов, показал, что следы макрофауны нельзя связать с фациальными геохимическими особенностями. Возможно, отсутствие связи палеонтологических находок и геохимических параметров пород вызвано грубым отбором образцов. Исследование следует продолжить на более детальном уровне, отбирая образцы для палеонтологического и геохимического изучения из тонких слоев (сантиметры, миллиметры).

Установлено, что седиментация ОВ происходила в условиях нормальной аэрации вод морского бассейна. Интенсивность химических и биохимических трансформаций минеральных и органических компонентов в диагенезе контролировалась содержанием органического углерода, сульфат-иона, активностью анаэробного сообщества прокариот, скоростью минерализации осадков. 
Работа выполнена в рамках проектов ФНИ 0331-2019-0003 «Палеонтологчческое и экостратиграфическое обоснование зональных стратиграфических схем палеозоя Сибири, палеогеографическое и биофациальное районирование осадочных бассейнов» и 0331-2019-0022 «Органическая геохимия и история геологического развития доминантных нефтегазовых систем верхнего протерозоя и фанерозоя Сибири».

\section{ЛИТЕРАТУРА}

Бахтуров С.Ф., Евтушенко В.М., Переладов В.С. Куонамская битуминозная карбонатно-сланцевая формация. Труды ИГиГ, вып. 671, Новосибирск: Наука, 1988, 160 с.

Каширцев В.А. Органическая геохимия нафтидов востока Сибирской платформы / Якутск: ЯФ Изд-ва СО РАН, 2003, 159 с.

Коровников И.В., Шабанов Ю.Я. Трилобиты пограничных отложений нижнего и среднего кембрия стратотипического разреза на р. Молодо (восток Сибирской платформы). // Разрезы кембрия Сибирской платформы - кандидаты в стратотипы подразделений международной стратиграфической шкалы (стратиграфия и палеонтология), Новосибирск, Изд-во СО РАН, 2008, с. 71-104.

Коровников И.В., Шабанов Ю.Я. Трилобиты и биостратиграфия куонамской свиты (р. Оленек, среднее течение). // Геология и геофизика, 2016, №4, с. 715-728.

Парфенова T.M., Бахтуров С.Ф., Шабанов Ю.Я. Органическая геохимия нефтепроизводящих пород куонамской свиты кембрия (восток Сибирской платформы). // Геология и геофизика, 2004, №7, с. 911-923.

Парфенова Т.М., Каширцев В.А., Коровников И.В. Новые находки нафтидопроявлений в породах среднего кембрия на северо-востоке Сибирской платформы // Нефтегазовая геология. Теория и практика: электрон. науч. журнал, 2014, т. 9, № 2, с. 1-22. http://www.ngtp.ru/rub/1/25_2014.pdf

Парфенова Т.М., Конторович А.Э., Борисова Л.С., Меленевский В.Н. Кероген куонамской свиты кембрия (северо-восток Сибирской платформы) // Геология и геофизика, 2010, № 3, с. 357-367. https://doi.org/10.1016/j.rgg.2010.02.004

Парфенова Т.М., Коровников И.В., Иванова Е.Н., Меленевский В.Н. Геохимия органического вещества нефтепроизводящих пород среднего кембрия (северо-восток Сибирской платформы) // Геология нефти и газа. - 2011. № 5. - С. 64-72.

Решения Всесоюзного стратиграфического совещания по докембрию, палеозою и четвертичной системе Средней Сибири. Новосибирск, 1983, 215 с.

Савицкий В.Е., Евтушенко В.М., Егорова Л.И., Конторович А.Э., Шабанов Ю.Я. Кембрий Сибирской платформы. М: Недра, 1972. 200 с. 
Старосельцев B.С., Шишкин Б.Б. Обстановки накопления углеродистых пород кембрия Сибирской платформы. // Геология и геофизика, 2014, № 5-6, с. 787-796.

Страхов Н.М., Залманзон Э.С. Распределение аутигенно-минералогических форм железа в осадочных породах и его значение для литологии // Известия академии наук СССР: серия геологическая, 1955, № 1, с. 34-51.

Шабанов Ю.Я., Коровников И.В., Переладов В.С., Пак К.Л., Фефелов А.Ф. Разрез куонамской свиты на р. Молодо - кандидат глобального стратотипа нижней границы среднего кембрия (восток Сибирской платформы) // Разрезы кембрия Сибирской платформы - кандидаты в стратотипы подразделений Международной стратиграфической шкалы (стратиграфия и палеонтология). Новосибирск, Изд-во СО РАН, 2008, с. $59-70$.

Connan J., Cassou A.M. Properties of gases and petroleum liquids derived from terrestrial kerogen at various maturation levels // Geochim. et Cosmochim. Acta, 1980, V. 44, p. $1-22$.

Dahl T.W., Siggaard-Andersen M., Niels H. Schovsbo N. H., Persson D. O., Søren Husted S., Hougård I. W. Dickson A. J., Kjaer K., Nielsen A. T., Brief oxygenation events in locally anoxic oceans during the Cambrian solves the animal breathing paradox. // Scientific Reports, $\mathrm{n}$ 9, 2019, p. 1-9.

Dutta S., Greenwood P.F., Brocke R., Schaefer R.G., Mann Ul. New insights into the relationship between Tasmanites and tricyclic terpenoids // Organic Geochemistry, 2006, V. 37, p. 117-127.

Greenwood P.F., Arouri K.R., George S.C. Tricyclic terpenoid composition of Tasmanites kerogen as determined by pyrolysis GC-MS // Geochim. et Cosmochim. Acta, 2000, V. 64, p. 1249-1263.

Parfenova T.M. Geochemistry of Sulfur and Sulfur Compounds of the Cambrian Kuonamka Complex (Eastern Siberian Platform) // Georesursy, 2017, V. 19, No. 1, p. 45-51. DOI: http://doi.org/10.18599/grs.19.1.8

Parfenova T.M. New geochemical data on the organic matter in rocks of the Lower and Middle Cambrian Kuonamka complex, the Lena-Amga Interfluve Area, southeastern Siberian Platform // Geochemistry International, 2018, V. 56, №. 5, p. 438-449. DOI: $10.1134 / \mathrm{S} 0016702918050051$

Parfenova T.M., Ivanova Y.N. Saturated and triaromatic steroids of aquagene organic matter of the Cambrian Kuonamka formation (eastern Siberian platform) // The 23th International meeting on organic geochemistry, 2007, Book of abstracts. P.Farrimond (eds.). Torquay. England. 9-14 September 2007, p. 491-492. 
Peters K.E., Walters C.C., Moldowan J.M. The biomarker guide. / Second Edition v. I, II, Cambridge University Press, 2005, 1155 p.

Santos Neto, E. V., Hayes J.M., Takaki T. Isotopic biogeochemistry of the Neocomian lacustrine and Upper Aptian marine-evaporitic sediments of the Potiguar Basin, northeastern Brazil // Organic Geochemistry, V. 28, № 6, 1998, p. 361-381. 


\section{Подписи к рисункам}

Рис. 1. Местонахождение изученных разрезов. Условные обозначения: 1 - граница Сибирской платформы; 2 - местоположение разрезов K-1 и K-2 на реке Кюленке.

Рис. 2. Стратиграфическое распространение трилобитов и уровни отбора образцов в изученных разрезах куонамской свиты на реке Кюленке. Условные обозначения: 1 органогенные известняки; 2 - глинистые известняки; 3 - черные сланцы; 4 - прослои песчанистого известняка; 5 - прослои силицитов; 6 - номера и точки отбора образцов с трилобитами; 7 - номера образцов для геохимических исследований; 8 - проявление битума.

Рис. 3. Диаграмма отношений пристана к n-C17, фитана к n-C18 [Connan J., Cassou, 1980] для битумоидов из пород куонамской свиты. Условные обозначения: 1 высокоуглеродистые черные сланцы, 2 - углеродистые глинисто-кремнистые известняки, глинисто-карбонатно-кремневые породы, 3 - черные силициты.

\section{Объяснения к таблицам.}

Таблица 1.

Фиг. 1-3. Oryctocephalops frischenfeldi Lermontova., 1940; 1 - кранидий; пачка 1, обр. K-2-18,7a; средний кембрий, амгинский ярус, зона Ovatoryctocara; 2 - пигидий, там же, обр. К-2-18,7б; 3 - целый панцирь, там же, К-2-18,7в.

Фиг. 4, 5. Pagetides spinosus Lazarenko, 1959; 4 - кранидии; пачка 1, обр. K-2-17,0a; средний кембрий, амгинский ярус, зона Ovatoryctocara; 5 - пигидий; там же, обр. обр. K-2$17,0 б$.

Фиг. 6. Kounamkites virgatus N.Tchernysheva, 1956; кранидий; кранидии; пачка 2, обр. K-2-15,5a; средний кембрий, амгинский ярус, зона Kounamkites.

Фиг. 7, 9. Pagetia ferox Lermontova, 1940; 7 - кранидий; пачка 2, обр. K-2-15,5б; средний кембрий, амгинский ярус, зона Kounamkites.; 9 - пигидий; пачка 3, обр. K-2-15,3а; средний кембрий, амгинский ярус, зона Kounamkites.

Фиг. 8, 10, 12. Oryctocephalus reticulatus (Lermontova, 1940); 8 - кранидий; пачка 2, обр. K-2-15,5в; средний кембрий, амгинский ярус, зона Kounamkites; 10 - кранидий; пачка 3, обр. K-2-15,3б; средний кембрий, амгинский ярус, зона Kounamkites; 12 - кранидий; кранидий; пачка 5, обр. K-2-10,5a; средний кембрий, амгинский ярус, зона Triplagnostus gibbus.

Фиг. 11, 13, 14. Peronopsis integra (Beyrich, 1845); 11 - цефалон и пигидий; пачка 3, обр. K-2-15,Зв; средний кембрий, амгинский ярус, зона Kounamkites; 13 - цефалон и 
противоотпечаток пигидия; там же, обр. К-2-15,3г; 14 - цефалон; пачка 2, обр. К-2-15,5г; средний кембрий, амгинский ярус, зона Kounamkites.

Фиг. 15, 16. Triplagnostus gibbus (Linnarsson, 1869); 15 - пигидий; пачка 6, обр. К-15,3а; средний кембрий, амгинский ярус, зона Triplagnostus gibbus; 16 - целый панцирь; там же, обр. К-1-5,3б.

Таблица 2.

Фиг. 1-5, 8, 9. Triplagnostus gibbus (Linnarsson, 1869); 1 - цефалон, пачка 6, обр. К-15,Зв; средний кембрий, амгинский ярус, зона Triplagnostus gibbus; 2, 3 - целые панцири; пачка 8, обр. K-1-3,4a, б; средний кембрий, амгинский ярус, зона Tomagnostus fissus Paradoxides sacheri; 4 - цефалон, там же, обр. K-1-3,4в; 5 - целый панцирь; там же, обр. K1-3,2a; 8 - цефалон и сегменты торакса; пачка 8, обр. K-1-0a; средний кембрий, амгинский ярус, зона Tomagnostus fissus - Paradoxides sacheri; 9 - цефалон; там же; обр. K-1-3,2.

Фиг. 6, 7. Tomagnostus fissus (Lungren, 1879); цефалоны; пачка 8, обр. К-1-3,2б, в; средний кембрий, амгинский ярус, зона Tomagnostus fissus - Paradoxides sacheri.

Фиг. 10-14. Aotagnostus (Myrmecomimus) arctus (Pokrovskaya et Jegorova, 1976); цефалоны и пигидии; пачка 8, образцы K-1-0 (б, в, г, д, е); средний кембрий, амгинский ярус, зона Tomagnostus fissus - Paradoxides sacheri.

Таблица 3. Состав пород куонамской свиты (р. Кюленке).

Таблица 4. Характеристика ОВ пород куонамской свиты (углеводороды, изотопный состав углерода). 
Таблица 1.
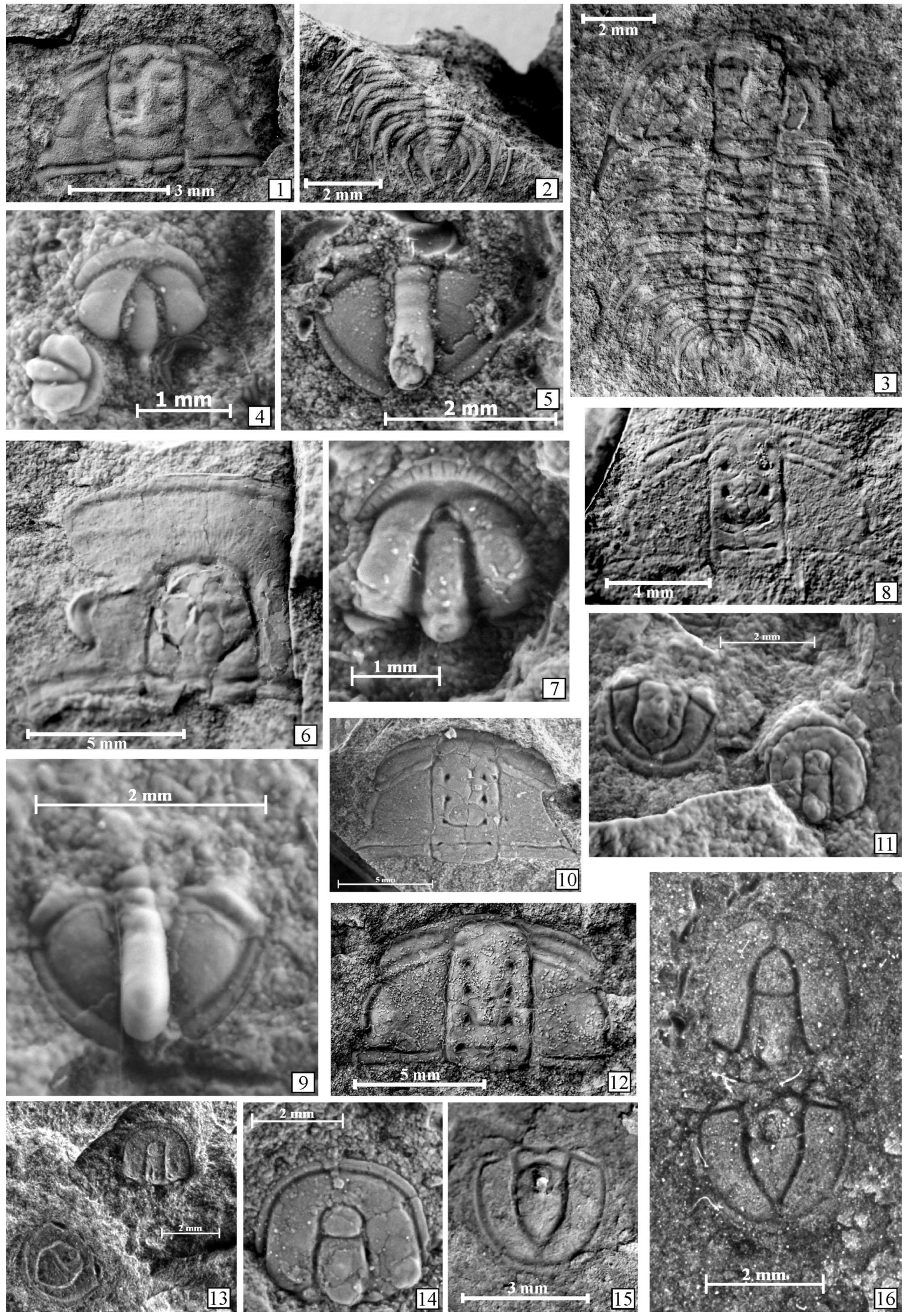
Таблица 2.
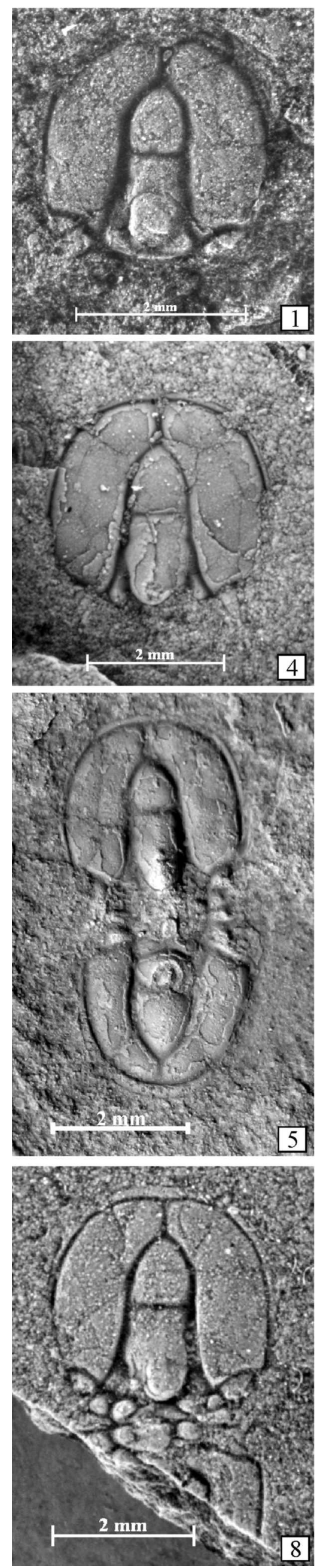
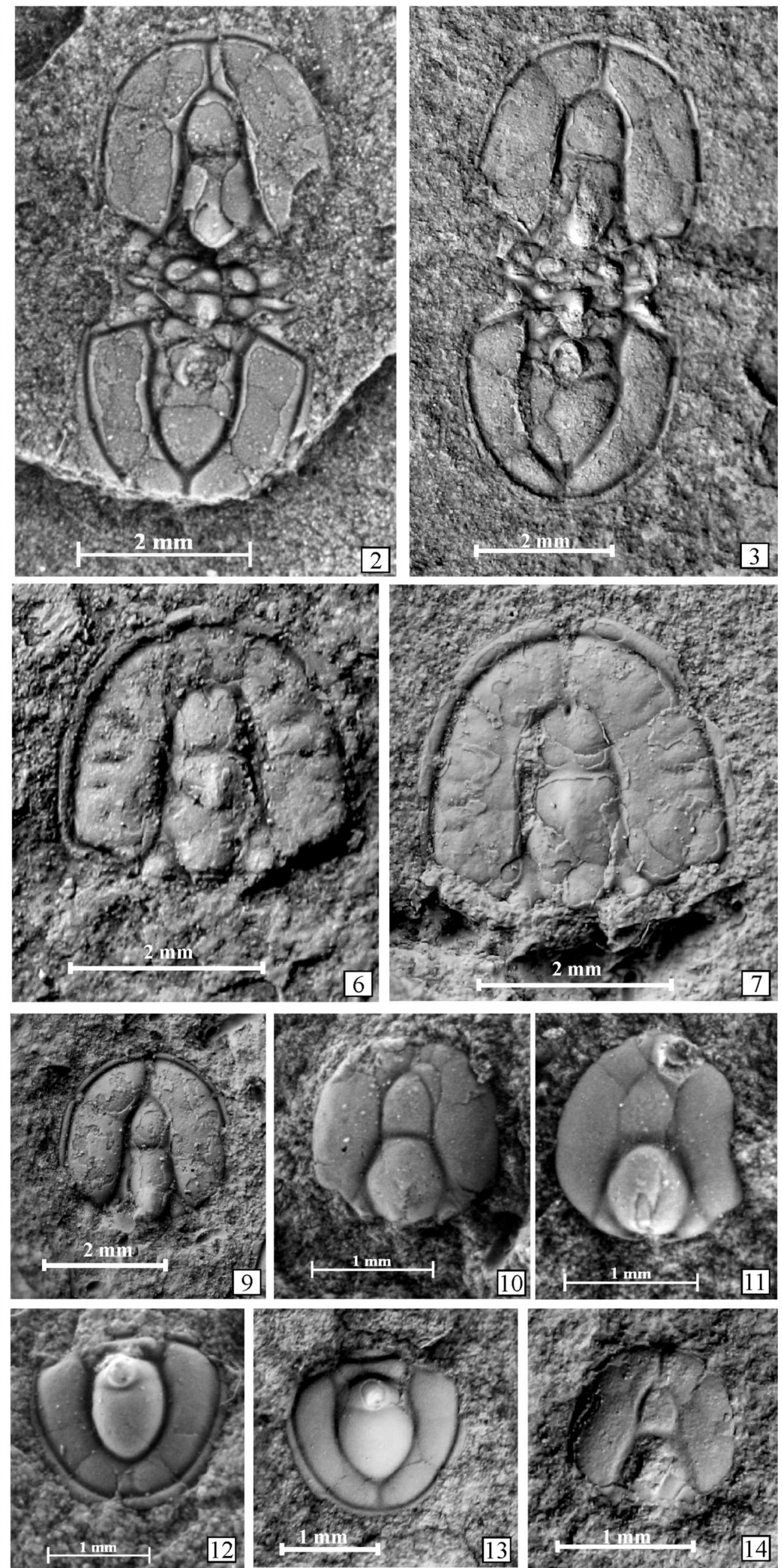


\begin{tabular}{|c|c|c|c|c|c|c|c|c|}
\hline \multirow{2}{*}{$\begin{array}{c}\text { № } \\
\text { образца }\end{array}$} & \multicolumn{7}{|c|}{ Содержание в \% на породу } & \multirow{2}{*}{$\begin{array}{c}\mathrm{Fe}_{\text {пирит }} / \\
\mathrm{C}_{\text {орг }}\end{array}$} \\
\hline & $\mathrm{HO}, \%$ & $\begin{array}{c}\mathrm{C}_{\text {opr }}, \\
\%\end{array}$ & $\mathrm{Fe}_{2} \mathrm{O}_{\text {Зобщ }}$ & $\mathrm{CO}_{2}$ & $\mathrm{~S}_{\text {общ }}$ & $\mathrm{S}_{\text {сульфат }}$ & $\mathrm{S}_{\text {сульфид }}$ & \\
\hline \multicolumn{9}{|c|}{ высокоуглеродистые черные сланцы } \\
\hline$K-2-2$ & 66,0 & 14,6 & 3,33 & 11,78 & 2,56 & 0,32 & 2,24 & 0,13 \\
\hline$K-2-4$ & 57,5 & 10,4 & 6,35 & 7,55 & 3,72 & 0,11 & 3,53 & 0,28 \\
\hline$K-2-6$ & 78,0 & 9,9 & 4,27 & 5,81 & 2,80 & 0,35 & 2,45 & 0,21 \\
\hline$K-2-10$ & 90,0 & 13,4 & 4,06 & 0,82 & 2,65 & 0,39 & 2,26 & 0,14 \\
\hline \multicolumn{9}{|c|}{ породы карбонатного и смешанного состава } \\
\hline$K-1-2$ & 55,6 & 3,5 & 2,81 & 17,27 & 1,15 & 0,05 & 1,10 & 0,26 \\
\hline$K-1-3$ & 55,2 & 3,7 & 3,54 & 14,28 & 1,81 & 0,05 & 1,76 & 0,40 \\
\hline$K-1-4$ & 64,4 & 4,1 & 2,60 & 13,28 & 1,17 & 0,07 & 1,10 & 0,23 \\
\hline$K-1-5$ & 50,8 & 0,9 & 0,83 & 19,01 & 0,39 & 0,05 & 0,34 & 0,31 \\
\hline$K-1-6$ & 43,2 & 2,8 & 1,35 & 19,51 & 0,73 & 0,05 & 0,68 & 0,20 \\
\hline$K-1-78$ & 37,6 & 0,3 & 0,52 & 15,24 & 0,30 & 0,02 & 0,28 & 0,92 \\
\hline$K-1-8$ & 53,4 & 2,5 & 1,46 & 18,01 & 0,71 & 0,04 & 0,67 & 0,22 \\
\hline$K-1-9$ & 48,4 & 1,2 & 1,14 & 20,26 & 0,75 & 0,10 & 0,65 & 0,46 \\
\hline$K-2-1$ & 55,5 & 3,4 & 3,54 & 14,53 & 1,93 & 0,12 & 1,81 & 0,45 \\
\hline$K-2-6 a$ & 16,0 & 0,7 & 1,56 & 28,48 & 0,62 & 0,04 & 0,58 & 0,70 \\
\hline$K-2-9$ & 27,0 & 4,2 & 0,94 & 29,97 & 0,73 & 0,05 & 0,68 & 0,14 \\
\hline \multicolumn{9}{|c|}{ черные силициты } \\
\hline$K-2-3$ & 94,5 & 1,9 & 0,73 & 0,82 & 0,27 & 0,12 & 0,15 & 0,07 \\
\hline$K-2-5$ & 91,5 & 3,8 & 1,04 & 3,06 & 0,50 & 0,03 & 0,47 & 0,10 \\
\hline$K-2-7$ & 93,0 & 5,2 & 1,04 & 1,82 & 0,60 & 0,07 & 0,53 & 0,09 \\
\hline$K-2-8$ & 95,5 & 3,7 & 0,83 & 0,57 & 0,56 & - & 0,56 & 0,13 \\
\hline
\end{tabular}

Таблица 3. Коровников И.В., Парфенова Т.М. 


\begin{tabular}{|c|c|c|c|c|c|c|c|c|c|c|c|c|c|c|c|c|c|}
\hline \multirow{3}{*}{$\begin{array}{c}\text { № } \\
\text { образц } \\
\text { а }\end{array}$} & \multirow{3}{*}{$\begin{array}{l}\mathrm{Pr} / \mathrm{n} \\
-\mathrm{C}_{17}\end{array}$} & \multirow{3}{*}{$\begin{array}{l}\mathrm{Ph} / \mathrm{n} \\
-\mathrm{C}_{18}\end{array}$} & \multicolumn{6}{|c|}{ Стераны } & \multicolumn{6}{|c|}{ Терпаны } & \multirow{3}{*}{$\begin{array}{c}\text { Трициклан } \\
\text { ы / } \\
\text { इ(Гопаны+ } \\
\text { Гомогопаны } \\
\text { ) }\end{array}$} & \multirow{3}{*}{$\begin{array}{c}\Sigma(\text { Стераны } \\
+ \\
\text { Прегнаны) } \\
/ \\
\Sigma(\text { Терпаны } \\
\text { ) } \\
\end{array}$} & \multirow{3}{*}{${ }^{\delta}$} \\
\hline & & & \multicolumn{4}{|c|}{ В \% от суммы } & \multirow{2}{*}{$\begin{array}{c}\mathrm{C}_{29} / \mathrm{C}_{2} \\
7\end{array}$} & \multirow{2}{*}{$\begin{array}{c}\text { Стераны/ } \\
\text { Прегнан } \\
\text { ы }\end{array}$} & \multicolumn{6}{|c|}{ В \% на сумму } & & & \\
\hline & & & $\mathrm{C}_{27}$ & $\mathrm{C}_{28}$ & $\mathrm{C}_{29}$ & $\begin{array}{c}\mathrm{C}_{3} \\
0\end{array}$ & & & $\begin{array}{c}\text { Гопан } \\
\text { ы }\end{array}$ & $\begin{array}{c}\text { Гомо- } \\
\text { гопан } \\
\text { ы } \\
\end{array}$ & $\begin{array}{l}\text { Море } \\
\text {-таны }\end{array}$ & $\begin{array}{c}\text { Трицик } \\
\text {-ланы }\end{array}$ & $\begin{array}{c}\text { Тетра- } \\
\text { циклан } \\
\text { ы }\end{array}$ & $\begin{array}{l}\text { Гамма } \\
\text {-церан }\end{array}$ & & & \\
\hline \multicolumn{18}{|c|}{ высокоуглеродистые черные сланцы } \\
\hline$K-2-2$ & 0,3 & 0,4 & $\begin{array}{c}40 \\
3\end{array}$ & $\begin{array}{c}20 \\
6\end{array}$ & $\begin{array}{c}37 \\
1\end{array}$ & $\begin{array}{c}2, \\
0\end{array}$ & 0,9 & 1,1 & 18,4 & 7,0 & 1,2 & 69,8 & 3,6 & 0,05 & 2,7 & 0,5 & $\begin{array}{c}- \\
32, \\
3\end{array}$ \\
\hline$K-2-4$ & 0,3 & 0,5 & $\begin{array}{c}43 \\
8\end{array}$ & $\begin{array}{c}18 \\
0\end{array}$ & $\begin{array}{c}35 \\
9\end{array}$ & $\begin{array}{r}2 \\
4\end{array}$ & 0,8 & 1,2 & 18,9 & 8,9 & 1,5 & 67,7 & 2,9 & 0,08 & 2,4 & 0,4 & $\begin{array}{c}- \\
31, \\
6\end{array}$ \\
\hline$K-2-6$ & 0,5 & 0,8 & $\begin{array}{c}36 \\
0\end{array}$ & $\begin{array}{c}13, \\
5\end{array}$ & $\begin{array}{c}48, \\
0\end{array}$ & $\begin{array}{l}2, \\
5\end{array}$ & 1,3 & 1,8 & 23,8 & 12,7 & 1,7 & 58,6 & 3,2 & 0,10 & 1,6 & 0,4 & $\begin{array}{c}- \\
32, \\
0\end{array}$ \\
\hline$K-2-10$ & 0,8 & 1,1 & $\begin{array}{c}36 \\
8\end{array}$ & $\begin{array}{c}17 \\
8\end{array}$ & $\begin{array}{c}43 \\
2\end{array}$ & $\begin{array}{l}2, \\
2\end{array}$ & 1,2 & 1,4 & 19,5 & 8,3 & 1,4 & 67,1 & 3,7 & 0,12 & 2,4 & 0,5 & $\begin{array}{c}- \\
30 \\
3\end{array}$ \\
\hline \multicolumn{18}{|c|}{ породы карбонатного и смешанного состава } \\
\hline$K-1-2$ & 0,8 & 0,8 & $\begin{array}{c}32, \\
2\end{array}$ & $\begin{array}{c}12 \\
4\end{array}$ & $\begin{array}{c}53 \\
0\end{array}$ & $\begin{array}{r}2, \\
4\end{array}$ & 1,6 & 2,6 & 24,9 & 14,3 & 1,6 & 56,7 & 2,5 & 0,65 & 1,4 & 0,4 & - \\
\hline$K-1-3$ & 0,7 & 0,7 & $\begin{array}{c}30 \\
9\end{array}$ & $\begin{array}{c}13, \\
0\end{array}$ & $\begin{array}{c}53, \\
5 \\
\end{array}$ & $\begin{array}{l}2, \\
6 \\
\end{array}$ & 1,7 & 2,8 & 25,9 & 15,3 & 1,8 & 54,6 & 2,3 & 0,66 & 1,3 & 0,5 & - \\
\hline$K-1-4$ & 0,5 & 0,8 & $\begin{array}{c}32 \\
6\end{array}$ & $\begin{array}{c}13 \\
2\end{array}$ & $\begin{array}{c}51, \\
8\end{array}$ & $\begin{array}{r}2 \\
4\end{array}$ & 1,6 & 2,3 & 26,5 & 13,7 & 1,8 & 55,5 & 2,5 & 0,58 & 1,4 & 0,5 & $\begin{array}{c}- \\
30 \\
3\end{array}$ \\
\hline$K-1-6$ & 0,7 & 0,8 & $\begin{array}{c}31, \\
3\end{array}$ & $\begin{array}{c}12 \\
5\end{array}$ & $\begin{array}{c}54, \\
0\end{array}$ & $\begin{array}{c}2, \\
2\end{array}$ & 1,7 & 3,0 & 27,7 & 16,4 & 1,5 & 51,8 & 2,5 & 0,77 & 1,2 & 0,4 & - \\
\hline$K-1-9$ & 0,5 & 0,5 & $\begin{array}{c}33 \\
4\end{array}$ & $\begin{array}{c}13 \\
2\end{array}$ & $\begin{array}{c}50 \\
7\end{array}$ & $\begin{array}{l}2 \\
8\end{array}$ & 1,5 & 3,2 & 23,6 & 13,0 & 1,4 & 59,7 & 2,4 & 0,76 & 1,6 & 0,5 & $\begin{array}{c}- \\
30, \\
1\end{array}$ \\
\hline$K-2-1$ & 0,4 & 0,6 & $\begin{array}{c}38 \\
3\end{array}$ & $\begin{array}{c}17, \\
0\end{array}$ & $\begin{array}{c}41, \\
2\end{array}$ & $\begin{array}{l}3, \\
6\end{array}$ & 1,1 & 3,3 & 33,2 & 16,6 & 2,3 & 45,2 & 2,7 & 1,61 & 0,9 & 0,5 & $\begin{array}{c}- \\
31, \\
9\end{array}$ \\
\hline$K-2-9$ & 0,8 & 1,2 & 32 & 13 & 52 , & 1 , & 1,6 & 3,1 & 28,1 & 16,0 & 2,0 & 50,9 & 3,1 & 0,22 & 1,2 & 0,3 & - \\
\hline
\end{tabular}




\begin{tabular}{|c|c|c|c|c|c|c|c|c|c|c|c|c|c|c|c|c|c|}
\hline & & & 6 & 4 & 3 & 8 & & & & & & & & & & & \\
\hline \multicolumn{18}{|c|}{ черные силициты } \\
\hline$K-2-3$ & 0,3 & 0,5 & $\begin{array}{c}31, \\
9\end{array}$ & $\begin{array}{c}12, \\
9\end{array}$ & $\begin{array}{c}52, \\
9\end{array}$ & $\begin{array}{l}2, \\
3\end{array}$ & 1,7 & 3,8 & 29,4 & 16,7 & 1,9 & 49,2 & 2,8 & 0,02 & 1,1 & 0,3 & - \\
\hline$K-2-5$ & 0,3 & 0,4 & $\begin{array}{c}32, \\
9\end{array}$ & $\begin{array}{c}12, \\
5\end{array}$ & $\begin{array}{c}52, \\
9\end{array}$ & $\begin{array}{l}1, \\
6\end{array}$ & 1,6 & 3,8 & 29,2 & 17,6 & 1,8 & 48,5 & 2,8 & 0,10 & 1,0 & 0,3 & $\begin{array}{c}31, \\
4\end{array}$ \\
\hline$K-2-7$ & 0,3 & 0,4 & $\begin{array}{c}31, \\
4\end{array}$ & $\begin{array}{c}13, \\
3\end{array}$ & $\begin{array}{c}53, \\
0\end{array}$ & $\begin{array}{c}2, \\
3\end{array}$ & 1,7 & 3,6 & 29,5 & 17,2 & 2,1 & 48,5 & 2,7 & 0,12 & 1,0 & 0,3 & $\begin{array}{c}30, \\
6\end{array}$ \\
\hline$K-2-8$ & 0,4 & 0,5 & $\begin{array}{c}31, \\
5\end{array}$ & $\begin{array}{c}13, \\
6\end{array}$ & $\begin{array}{c}52, \\
2\end{array}$ & $\begin{array}{l}2, \\
7\end{array}$ & 1,7 & 4,1 & 28,6 & 17,3 & 1,9 & 49,3 & 2,9 & 0,11 & 1,1 & 0,3 & $\begin{array}{c}32, \\
6\end{array}$ \\
\hline
\end{tabular}

Таблица 4. Коровников И.В., Парфенова Т.М. 


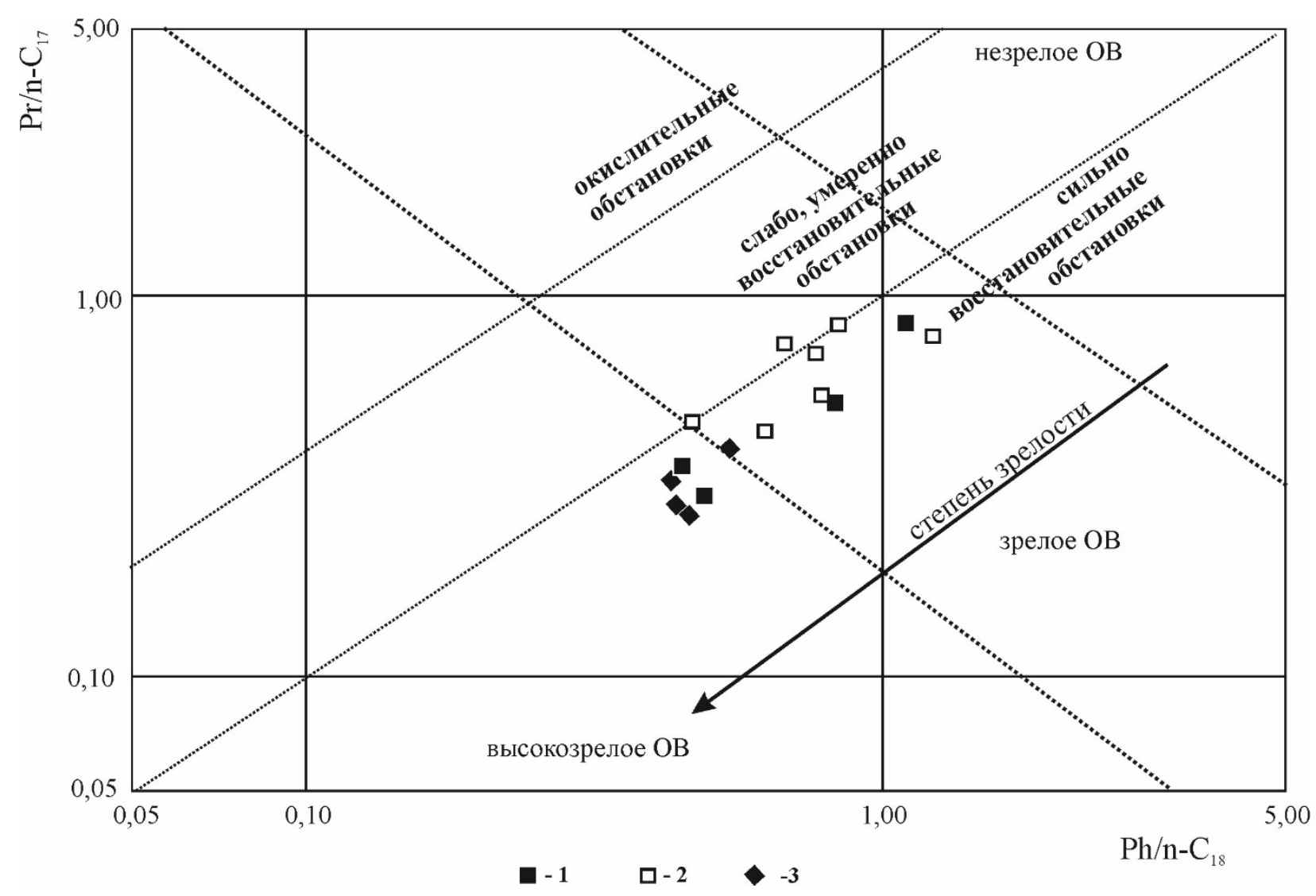

Рис. З. Коровников И.В., Парфенова Т.М. 


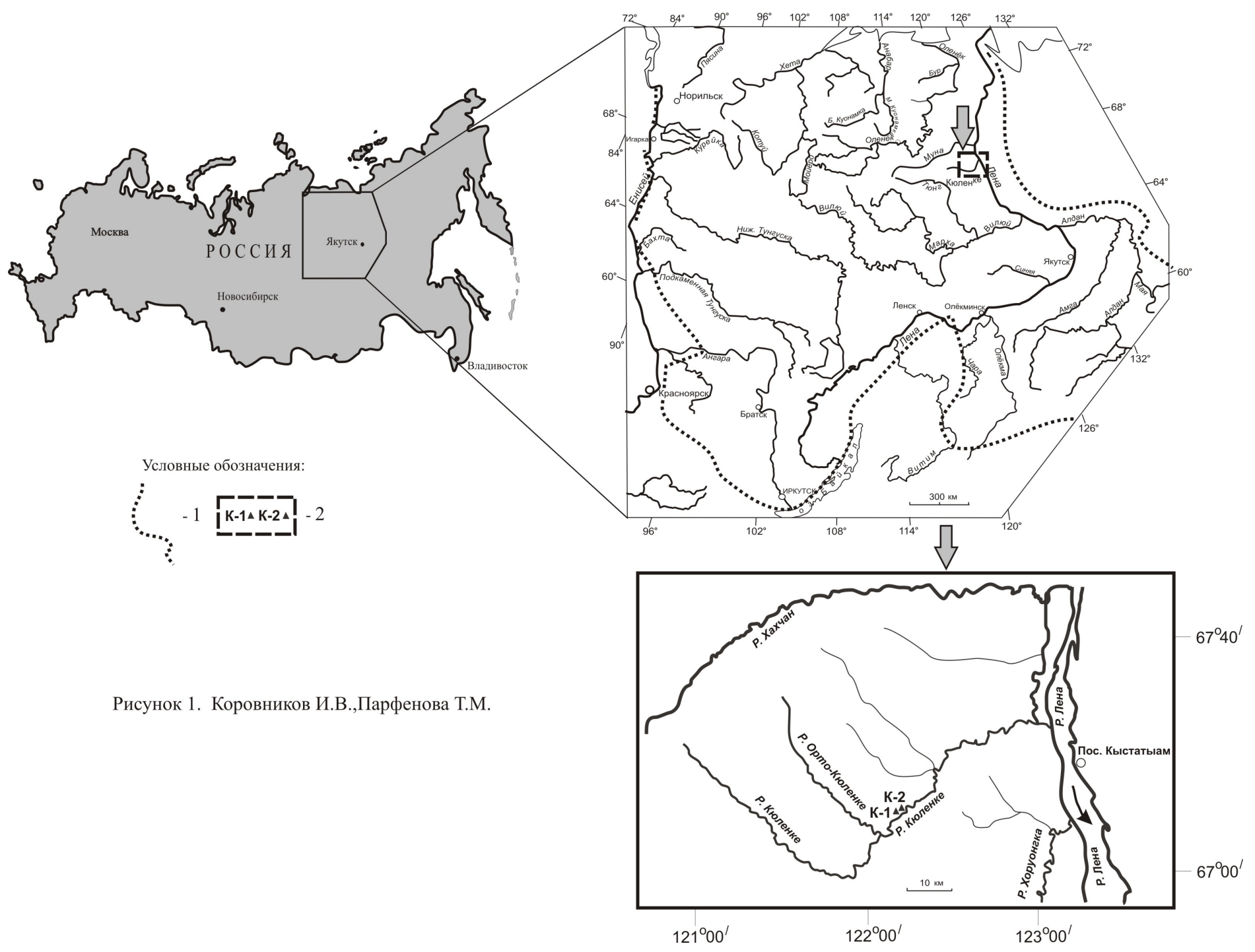




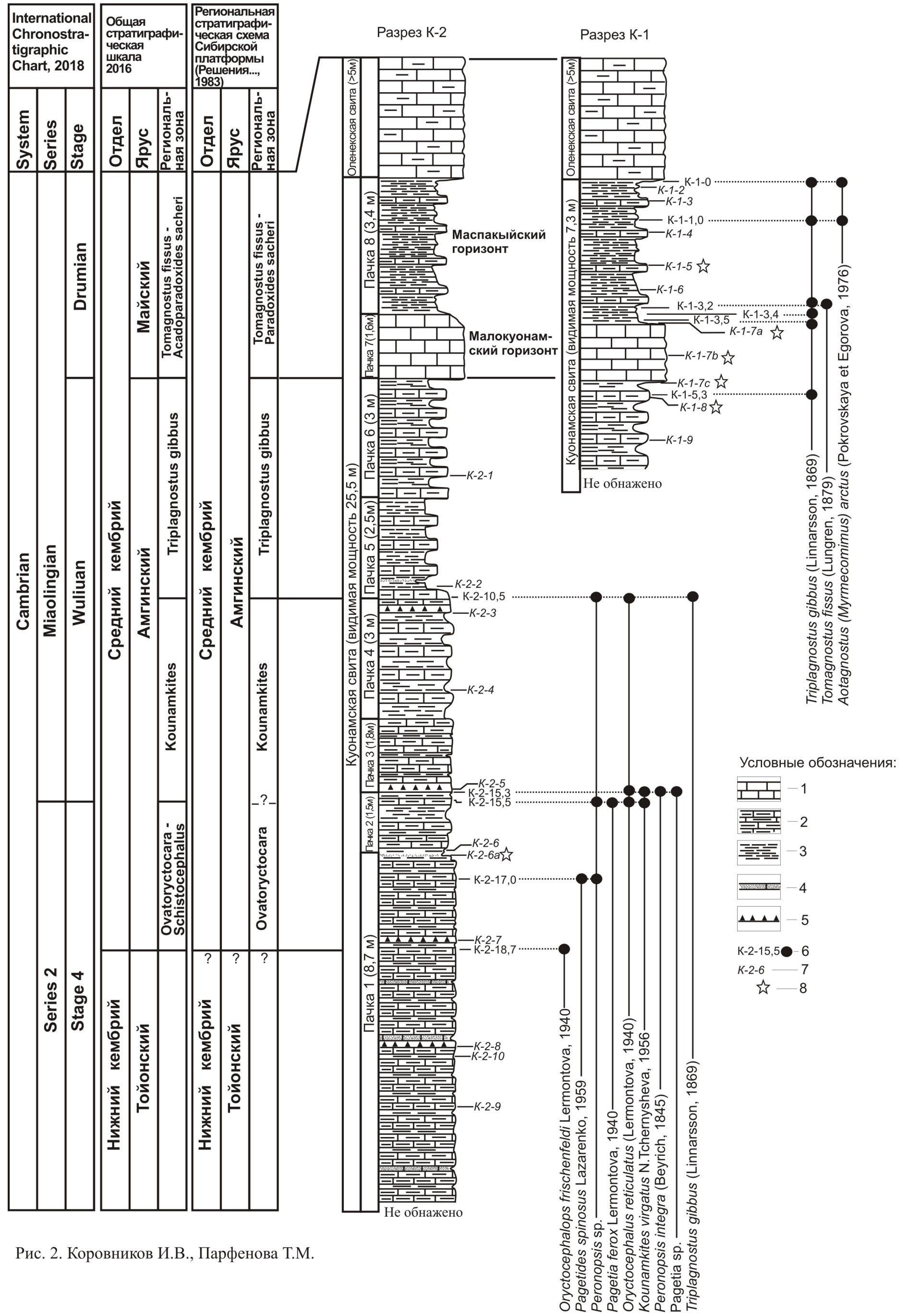

